\title{
PERUBAHAN KUALITAS MINYAK GORENG AKIBAT LAMANYA PEMANASAN
}

\author{
M. Manurung, N. M. Suaniti, dan K. G. Dharma Putra \\ Program Studi Kimia F.MIPA,Universitas Udayana \\ Email: manuntunmanurung@unud..ac.id, madesuaniti@unud..ac.id, kgdharmap@gmail.com
}

\begin{abstract}
ABSTRAK
Penggunaan minyak goreng secara berulang-ulang atau pemanasan minyak yang lama dapat mengubah sifat fisiko-kimia dari minyak baik minyak kemasan ataupun minyak curah. Perubahan ini menjadi ciri awal adanya kerusakan dari minyak goreng tersebut. Penelitian ini bertujuan untuk menentukan perubahan kualitas minyak goreng akibat proses pemanasan, yang mengacu pada SNI - 2002. Syarat mutu dilihat dari bilangan peroksida(BP), bilangan Iod(BI), bilangan asam (BA) dan persentase asam lemak bebas (\% FFA). Hasil penelitian menunjukkan, hingga pemansan 40 menit harganya berturut-turut untuk minyak kemasan $\mathrm{BP}=6,225$ meqO2/100g; $\mathrm{BI}=32,464 \mathrm{~g} \mathrm{Iod} / 100 \mathrm{~g} ; \mathrm{BA}=0,748 \mathrm{mgKOH} / \mathrm{g} ; \% \mathrm{FFA}=0,356 \%$; sedangkan untuk minyak curah adalah $\mathrm{BP}=6,874 \mathrm{meq} / 100 \mathrm{~g} ; \mathrm{BI}=25,37 \mathrm{~g} . \mathrm{Iod} / 100 \mathrm{~g} ; \mathrm{BA}=1,096 \mathrm{mgKOH} / \mathrm{g} ; \% \mathrm{FFA}=0,513$. Warna minyak berubah kuning kecoklatan menjadi coklat kehitaman.
\end{abstract}

Kata kunci: bilangan asam, bilangan Iod, bilangan peroksid, \% FFA, minyak goreng

\begin{abstract}
The use of frying oil repeatedly or heating the oil for a long time at high temperatures can change the physico-chemical properties of either branded or bulk oils. The changes are an early indicator of damage of the oils. This research aimed to determine the changes of frying oils quality as a consequence of heating process, which refers to SNI-2002. The quality requirements was investigated in terms of peroxide number, iodine number, acid number and free fatty acids percentage. When the branded oils were heated up to 40 minutes, it was found as follows: the BP number was of $6.225 \mathrm{meq} / 100 \mathrm{~g}$, BI number was of $32.464 \mathrm{~g}$ Iod $/ 100 \mathrm{~g}$, BA was of $0.748 \mathrm{mg} \mathrm{KOH} / \mathrm{g}$, \%FFA was of 0.356; while for the bulk oil, the results found were as follows: BP number was of $6.874 \mathrm{meq} / 100 \mathrm{~g}$, BI number was of $25.37 \mathrm{~g} \mathrm{Iod} / 100 \mathrm{~g}$, BA number was of $1.096 \mathrm{mg} \mathrm{KOH} / \mathrm{g}$ and \% FFA was of 0.513 . The colour of the frying oils was observed to change from brownish yellow to brownish black. Evidently, both type of cooking oils tend to damage when they are heated at high temperatures.
\end{abstract}

Keywords: acid number, cooking oil, iodine number, peroxide number, FFA percentage

\section{PENDAHULUAN}

Minyak goreng merupakan media memasak yang popular di masyarakat, karena mudah didapat dan harganya relative terjangkau. Pilihannya juga tersedia dalam bentuk kemasan atau curah. Kalangan masyarakat golongan menengah bawah dan pedang kecil cenderung menggunakan minyak curah, sebab harganya lebih murah. Penggunaannya sering kali digunakan secara berulang-ulang, hingga warnanya berubah menjadi kehitaman Mereka tidak peduli atau tidak mengetahui dampaknya bagi kesehatan bila terus menerus mengkonsumsi makanan hasil olahan seperti ini. Menurut Alyas et al. (2009), pemanasan dapat menyebabkan kandungan $\quad \beta$-karoten dalam minyak berubah.Kualitas minyak goreng ditentukan oleh komponen asam lemak penyusunnya yaitu asam lemak jenuh dan tak jenuh. Asam lemak jenuh lebih mudah terhidrolisis dan asam lemak tak jenuh mengalami oksidasi. Reaksi lain yang penting adalah hidrogenasi ikatan rangkap menjadi ikatan tunggal (Ketaren, 1986).

Paparan oksigen dan proses pemanasan dapat mempercepat terjadinya oksidasi minyak.goreng membentuk peroksida, seterusnya menjadi aldehid dan komponen radikal bebas yang berpengaruh terhadap pertumbuhan sel kanker. Pemanasan minyak menyebabkan terjadinya oksidasi, hidrolisis dan dekomposisi minyak, yang di pengaruhi 
tingginya suhu dan lamanya pemanasan (Chatzilzaron, et al., 2006). Penelitian Yoon dan Choe (2007), melaporkan akibat oksidasi minyak goreng dapat meningkatkan kandungan asam lemak bebas (FFA). Asri (2013) mengatakan bahwa pemakaian minyak goreng berpengaruh terhadap kualitas minyak yang dapat dilihat dari perubahan bilangan peroksida. Selanjutnya Siti Aminah (2010) dan Onny (2014) juga melaporkan bahwa pemanasan dapat berpengaruh terhadap bilangan peroksida minyak goreng curah. Akibat lain dari pemanasan minyak goreng adalah terbentuknya hidrokarbon aromatic polisiklik (polycyclic aromatic hydrocarbon, $P A H)$ seperti fenantren dan benzopyren. Senyawa ester-ester asam lemak yang terdapat dalam minyak dapat dideteksi setelah diekstrak dengan etanol dan senyawa PAH ditentukan melalui gugus fungsi aldehid aromatiknya (Suaniti , 2011)

Berdasarkan hal tersebut perlu dilakukan penelitian penentuan perubahan sifat fisika kimia dari minyak kemasan dan minyak curah akibat lamanya pemanasan, meliputi Bilangan Peroksida, Bilangan Iod, Bilangan asam dan FFA melalui uji titrasi dan perubahan warnanya melalui pengamatan visual.

\section{MATERI DAN METODE}

\section{Bahan}

Bahan yang digunakan dalam penelitian ini berkualitas pro analisis kecuali bahan sampel meliputi; Kloroform, $\mathrm{HCl} 37 \%$, $\mathrm{KOH}$, Etanol 96\%, Asam Oksalat, indikator $\mathrm{PP}$, metil merah, amilum, natrium tiosulfat, $\mathrm{KI}$, $\mathrm{NaHCO}_{3}, \quad \mathrm{~K}_{2} \mathrm{Cr}_{2} \mathrm{O}_{7}, \quad$ Asam asetat glasial, $\mathrm{Na}_{2} \mathrm{CO}_{3}$, Aseton, $\mathrm{I}_{2}$, dan $\mathrm{Br}_{2}$. Bahan sampel adalah minyak kemasan dan minyak curah.

\section{Peralatan}

Alat-alat yang digunakan dalam penelitian ini adalah seperangkat peralatan gelas seperti buret, labu ukur, Erlenmeyer, pipet volume, statif, dan beaker gelas.

\section{Cara Kerja}

\section{Penyiapan Sampel}

Minyak goreng curah dibeli di Pasar Tradisional dari Pasar Badung, dan minyak kemasan di beli dari pasar Swalayan. Pemanasan minyak dilakukan secara bervariasi dari 10, 20, 30, dan 40 menit. Kemudian ditentukan sifat fisikokimianya (dilakukan sebanyak tiga kali ulangan).

\section{Penentuan Sifat Kimia.}

Bilangan Peroksida (Sudarmaji et al., 1989)

Sebanyak $25 \mathrm{~g}$ minyak dimasukkan ke dalam Erlenmeyer, serta ditambahkan $30 \mathrm{~mL}$ asam asetat glasial dan kloroform dengan perbandingan 3:2, lalu dikocok hingga minyak larut. Selanjutnya ditambahkan $0,5 \mathrm{~mL}$ larutan KI jenuh ditutup rapat sambil dikocok. Didiamkan 1-2 menit, ditambahkan $30 \mathrm{~mL}$ aquades, lalu dititrasi dengan $\mathrm{Na}_{2} \mathrm{~S}_{2} \mathrm{O}_{3} 0,10 \mathrm{~N}$ hingga warna kuning hampir hilang, ditambahkan $0,5 \mathrm{~mL}$ indicator amilum $1 \%$, terbentuk warna biru, dititrasi terus hingga warna biru hilang.

\section{Bilangan Iod (Jacobs, 1973)}

Sebanyak 0,5 g minyak dimasukkan ke dalam Erlenmeyer bertutup, ditambahkan 10 $\mathrm{ml}$ kloroform dan $25 \mathrm{~mL}$ pereaksi Jodium bromida. Disimpan dalam ruang gelap dan sesekali dikocok. Selanjutnya ditambahkan 10 $\mathrm{mL}$ larutan KI 15\% dan aquades, dan segera dititrasi dengan larutan $\mathrm{Na}_{2} \mathrm{~S}_{2} \mathrm{O}_{3}, 0,1 \mathrm{~N}$ sampai warna kuning pucat, ditambah $2 \mathrm{~mL}$ larutan amilum. Titrasi terus sampai warna biru hilang. -Bilangan Asam dan FFA (Sudarmaji et al., 1989)

Sebanyak $2 \mathrm{~mL}$ minyak di masukkan ke dalam Erlenmeyer.ditambahkan $2 \mathrm{~mL}$ alkohol 95\%, lalu dipanaskan selama 10 menit di penangas sambil dikocok, kemudian didinginkan. Dititrasi dengan larutan KOH 0,1 $\mathrm{N}$ dengan indicator fenolftalein hingga terbentuk warna pink.

$$
\text { Kadar FFA }=\frac{\mathrm{V} \times \mathrm{N} \times \mathrm{BM}_{\text {asam lemak }} \times 100 \%}{\mathrm{G} \times 1000}
$$

Keterangan :

$$
\begin{aligned}
& \mathrm{V}=\text { volume } \mathrm{KOH} \text { titrasi }(\mathrm{mL}) \\
& \mathrm{N}=\text { normalitas } \mathrm{KOH} \\
& \mathrm{G}=\text { massa minyak }(\mathrm{g})
\end{aligned}
$$

$$
\text { Bil. Asam }=\frac{\text { Kadar FFA x BM KOH x } 10}{\text { BM }_{\text {asam palmitat }}(256,4 \mathrm{~g} / \mathrm{mol})}
$$




\section{HASIL DAN PEMBAHASAN}

Hasil pengukuran sifat fisikokimia minyak goreng komersial dan curah, meliputi bilangan Iod, bilangan peroksida, bilangan asam dan asam lemak bebas (FFA) disajikan dalam Tabel 1.

Berdasarkan data hasil pengamatan yang terdapat di Tabel 1, terdapat kecenderungan penurunan bilangan Iod dari minyak goreng terhadap lamanya pemanasan. Bilangan Iod untuk minyak kemasan dan curah sebelum pemanasan (Kontrol) berturut 54,734 dan 50,722 g Iod/100g semakin lama pemanasan minyak, terjadi penurunan bilangan Iod (Gambar 1), ada korelasi positif antara pemanasan terhadap perubahan bilangan Iod yang dinyatakan oleh nilai $\mathrm{R}^{2}>0,9$. Pada pemanasan 20 menit minyak curah mempunyai BI sebesar 35,124 lebih kecil dari persyaratan SNI 1995 BI sekitar 45-46. Minyak kemasan relatif lebih bertahan, artinya minyak goreng curah lebih mudah teroksidasi, dibandingkan minyak kemasan. Penurunan Bilangan Iod untuk dua jenis minyak memberikan gambaran pengurangan ikatan rangkap dalam komponen minyak, akibat terjadinya oksidasi/pemecahan ikatan rangkap atau hidrogenasi selama pemanasan membentuk senyawa aldehid, epoksi, keton, atau molekul lain yang bersifat radikal atau asam lemak bebas (Ketaren, 1986).

Semakin lama pemanasan menyebabkan suhu minyak goreng semakin tinggi. Pada pemanasan 30- 40 menit minyak mulai keluar asap yang pada kondisi ini disebutkan suhu minyak lebih dari $190^{\circ} \mathrm{C}$ (Chatzilazaron, 2006). Hal tersebut mengakibatkan terjadinya proses oksidasi, hidrolisis, dan polimerisasi asam lemak tidak jenuh sehingga terbentuk senyawa keton, aldehid, dan polimer (Mulyati, et al., 2015).

Bilangan peroksida untuk kedua minyak goreng mengalami kenaikan (Gambar 2) yang berarti minyak mengalami oksidasi membentuk peroksida, akibatnya jumlah peroksida meningkat dalam minyak jelantah. Oksidasi lebih lanjut akan menghasilkan keton, aldehid, dan asam karboksilat. Hasil ini sesuai dengan pengamatan Aminah, 2010 dan Onny, 2014 yang memberikan pola yang mirip. Nilai Bilangan Peroksida untuk minyak goreng Curah, dan kemasan berturut-turut 5,332 meq $\mathrm{O}_{2} / \mathrm{kg} ; 4,211 \mathrm{meq} / \mathrm{kg}$ masih lebih rendah dari 10 (SNI-2013).
Bilangan asam menunjukkan jumlah total asam bebas dalam minyak. Semakin lama proses pemanasan menyebabkan jumlah kandungan asam dalam minyak meningkat (Gambar 3) karena dengan pemanasan laju reaksi hidrolisis minyak membentuk asam lemak bebas bertambah cepat. Asam lemak bebas adalah sebanyak atau sejumlah asam lemak bebas yang terkandung dalam minyak akibat pemanasan dan hidrolisis sehingga kualitas minyak dikatakan menurun. Penggorengan minyak secara berulang mengakibatkan rusaknya asam-asam lemak tak jenuh dalam minyak sehingga kualitas minyak telah menurun (Ilmi, et al., . 2015).

Peningkatan bilangan asam erat kaitannya dengan bertambahnya asam-asam lemak bebas (FFA) akibat hidrolisis minyak menjadi asam lemak dan gliserol (Gambar 4). Setiap peningkatan suhu $10^{\circ} \mathrm{C}$ laju oksidasi dua kali lebih cepat. Kandungan bilangan asam yang melebihi 0,6 $\mathrm{mgKOH} / \mathrm{g}$ (SNI-2013) khusus minyak goreng curah hanya bertahan hingga 20 menit dan kemasan relatif lebih lambat. Sedangkan warna minyak dapat dilihat berubah dari sebelum pemanasan berwarna kuning namun setelah pemanasan menjadi coklat, terutama setelah pemanasan 30 hingga 40 menit, kemungkinan pewarna dalam minyak telah mengalami degradasi. Kadar FFA yang tinggi, selain akibat pemanasan juga akibat kandungan karoten, tokoferol, dan alkohol dalam jumlah kecil dalam minyak (Mulyati, et al., 2015). 


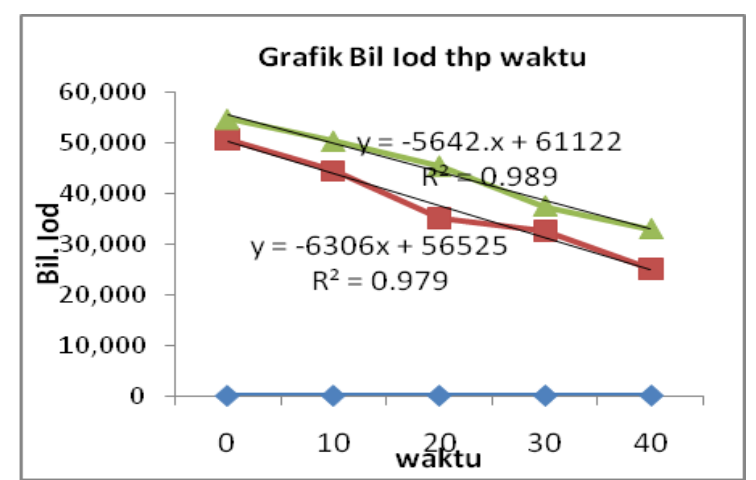

Gambar 1. Grafik Bilangan Iod terhadap waktu

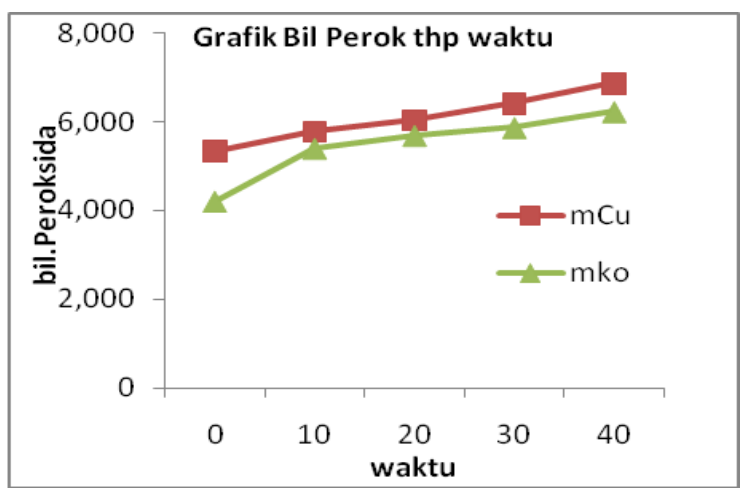

Gambar 2. Grafik Bilangan Peroksida terhadap waktu

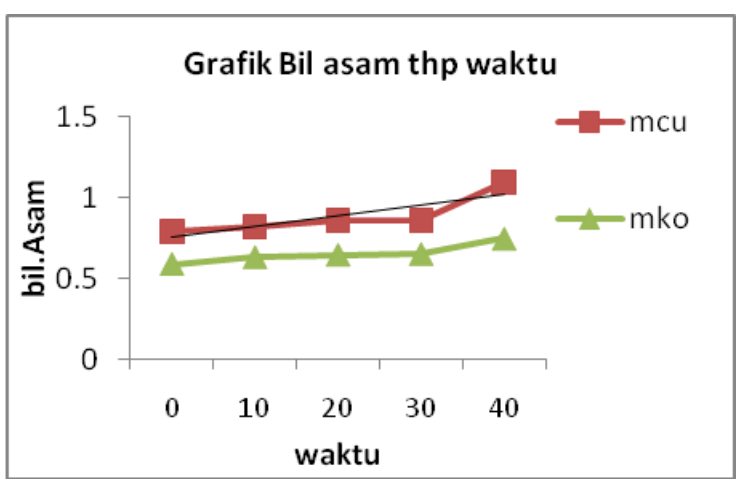

Gambar 3. Grafik Bilangan Asam terhadap waktu

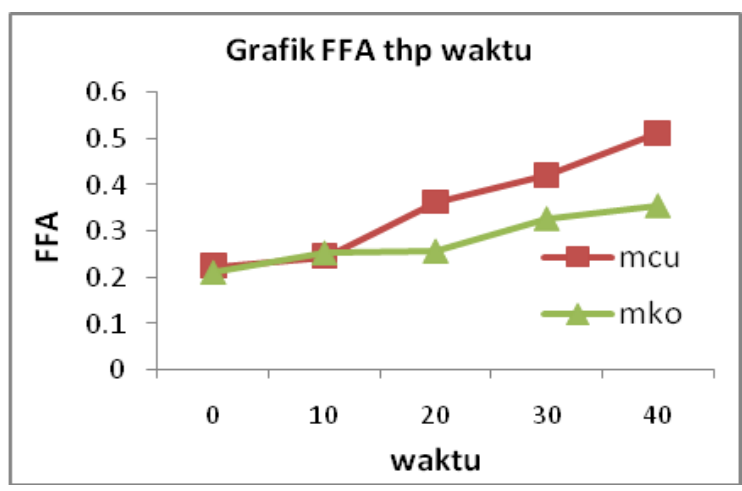

Gambar 4. Grafik FFA terhadap Waktu

Tabel 1. Sifat fisikokimia minyak goreng kemasan dan curah.selama pemanasan

\begin{tabular}{|c|c|c|c|c|c|c|c|c|}
\hline \multirow{2}{*}{$\begin{array}{l}\text { Lama } \\
\text { pema } \\
\text { nasan } \\
\text { (menit) }\end{array}$} & \multicolumn{2}{|c|}{$\begin{array}{c}\text { Bilangan Iod (BI) } \\
\text { g Iod/100g }\end{array}$} & \multicolumn{2}{|c|}{$\begin{array}{l}\text { Bil peroksi (BP) } \\
\left(\mathrm{meqO}_{2} / \mathrm{kg}\right)\end{array}$} & \multicolumn{2}{|c|}{$\begin{array}{c}\text { Bil Asam (BA) } \\
(\mathrm{mg} \mathrm{KOH} / \mathrm{g})\end{array}$} & \multicolumn{2}{|c|}{$\begin{array}{l}\text { FFA } \\
\% \mathrm{~b} / \mathrm{b}\end{array}$} \\
\hline & Curah & Kemas & Curah & Kemas & Curah & kemas & curah & Kemas \\
\hline 0 & 50,722 & 54,734 & 5,332 & 4,211 & 0,792 & 0,589 & 0,224 & 0,212 \\
\hline 10 & 44,472 & 50,368 & 5,773 & 5,404 & 0,821 & 0,632 & 0,245 & 0,254 \\
\hline 20 & 35,124 & 45,421 & 6,032 & 5,691 & 0,861 & 0,647 & 0,364 & 0,258 \\
\hline 30 & 32,582 & 37,480 & 6,412 & 5,869 & 0,863 & 0,652 & 0,422 & 0,328 \\
\hline 40 & 25,137 & 32,964 & 6,874 & 6,225 & 1,096 & 0,748 & 0,513 & 0,356 \\
\hline
\end{tabular}




\section{SIMPULAN DAN SARAN}

\section{Simpulan}

Semakin lama pemanasan minyak goreng baik kemasan ataupun curah Bilangan Iod, nya semakin berkurang, sedangkan Bilangan Peroksida, Bilangan Asam dan kadar FFA semakin bertambah.

Minyak goreng kemasan relatif lebih tahan terhadap pemanasan dibandingkan dengan minyak goreng curah dalam waktu yang sama, namun kedua jenis minyak mengalami kerusakan akibat pemanasan.

\section{Saran}

Agar penjual minyak goreng curah lebih memperhatikan tempat penyimpanan, dan tidak kena sinar matahari. Perlu dilakukan lebih lanjut analisis dari komponen utama dari minyak goreng sebelum dan setelah pemanasan.

\section{UCAPAN TERIMAKASIH}

Ucapan terimakasih Penulis kepada Ketua LPPM-melalui Dekan FMIPA Unud yang memberikan Pendanaan melalui Hibah Unggulan Program Studi (HUPS) 2016. Terima kasih juga kepada mahasiswa (S1) Meryana Utami dan Teja yang telah membantu pengumpulan data, demi kelancaran penelitian ini.

\section{DAFTAR PUSTAKA}

Alyas, S. A., Abdullah, A., and Idris, N. A., 2006, Change of $\beta$-Charotene Content During Heating of Red Palm Olein, Journal of Oil Research ( Special Issu April 2009): 99-120.

Asri, S. S., 2013, Kualitas Minyak Goreng Habis Pakai Ditinjau Dari Bilangan Peroksida, Bilangan Asam dan Kadar Air, Pusat Biomedis dan Teknologi Dasar Kesehatan Balai Litbangkes, Kemenkes RI.

Aminah, S., 2010, Bilangan Peroksida Minyak Goreng Curah dan Sifat Organoleptik Tempe pada Pengulangan Penggorengan, Jurnal pangan dan Gizi, 1 (1): 7-14.
Chatzilazaron, A., Gartzi, O., Lalas, S., Zoidis, E., and Tsaknis, J., 2006, Phsycochemical Changes Of Olive Oil and Selected Vegetabel Oils During Frying, Journal Food Lipids, 13: 2735.

Ilmi, I. M. B., Khomsan, A., Marliyati, S. A., 2015, Kualitas Minyak Goreng dan Produk Gorengan Selama Penggorengan di Rumah Tangga Indonesia, Jurnal Aplikasi Pangan, 4 (2): 61-65.

Jacobs, M. B., 1973, The Chemical Analysis of Food and Food Products, Roberts Krieger Publishing Co., Inc., New York.

Ketaren, S., 1986, Pengantar Teknologi Minyak dan Lemak Pangan, UI Press., Jakarta.

Mulyati, T.A., Pujiono, F.E., Lukis, P.A., 2015, Pengaruh lama pemanasan terhadap kualitas minyak goreng kemasan kelapa sawit, Jurnal Wiyata, 2 (2): 162-168

Onny, J. D. S. dan Any, G., 2014, Aktivitas antioksidan ekstrak buah manggis pada minyak goreng curah kelapa sawit, Jurnal Farmasi sains, 2 (3): 122-128

Standar Nasional Indonesia (SNI), 01-37412013, Minyak Goreng, Badan Standarisasi Nasional, Jakarta.

Standar Nasional Indonesia (SNI), 01-37412002, Kualitas Minyak Goreng, Badan Standarisasi Nasional, Jakarta.

Sudarmaji, Slamet, Suhardi, dan Haryono, B, 1989, Analisis Bahan Pangan dan Pertanian, PAU Pangan dan Gizi UGM, Yogyakarta.

Suaniti, N. M., 2011, Aplikasi Teknologi Solid Phase Extractions senyawa etil palmitat dalam serum Tikus Wistar dan Analisis GC-MS, Prosiding Seminar Nasional Kimia Terapan Indonesia, ISSN: 2088-9825: 8-12. 
JURNAL KIMIA 12 (1), JANUARI 2018: 59 - 64

Yoon, Y. and Choe, E., 2007, Oxidation of Corn Oil during Frying of Soy-Flour-
Added Flour Dough, Journal of Food

Science, 72(6): 317-323 